\title{
CLINICAL AND EPIDEMIOLOGICAL STUDY OF 27 POISONINGS CAUSED BY INGESTING PUFFER FISH (TETRODONTIDAE) IN THE STATES OF SANTA CATARINA AND BAHIA, BRAZIL
}

\author{
Claudia Carvalho Pestana SILVA(1), Marlene ZANNIN(2), Daisy Schwab RODRIGUES(3), Claudia Regina dos SANTOS(2),
} Ieda Ana CORREA(1) \& Vidal HADDAD JUNIOR(4)

\begin{abstract}
SUMMARY
Puffer fish can be poisonous due to the presence of the potent neurotoxins such as Tetrodotoxin (TTX) and Saxitoxin (STX) found in its tissues. The authors report 27 human poisonings from ingestion of puffer fish in patients treated at Toxicology Centers in the states of Santa Catarina and Bahia, Brazil, between 1984 and January 2009. Poisonings were classified as moderate (52\%) and severe (33\%), two deaths were observed. Early diagnosis is very important to ensure respiratory support.
\end{abstract}

KEYWORDS: Puffer fish;Tetrodotoxin; Poisonous fish; Saxitoxin; Human poisoning.

\section{INTRODUCTION}

The puffer fish (known as "baiacu" in Brazil) is a widely distributed bony fish. There are about 120 species worldwide; most of them are found in tropical and subtropical regions, and there are also freshwater species. When threatened by predators, they can ingest water or air to increase their body volume and take on a spherical shape that hinders the action of larger fish ${ }^{20}$.

Puffer fish are poisonous due to the presence of Tetrodotoxin (TTX) and occasionally Saxitoxin (STX) in their body tissues, both lethal neurotoxins. TTX is probably synthesized by bacteria found in the foods they eat. This toxin accumulates in the fish, to be used as a defense weapon and is mainly found in the viscera (especially the gonads, liver, and spleen) and the skin of the fish ${ }^{26}$. STX is produced by microalgae ${ }^{8}$. STX accumulates by feeding on bivalves that have ingested toxic dinoflagellate such as Alexandrium tamarense $e^{19}$ and Pyrodinium bahamense $e^{17}$.

TTX is a thermo-stable toxin, which does not degenerate when exposed to high temperatures, washing or freezing ${ }^{18}$. Toxin levels are seasonal with the highest concentrations found in females at the peak of their reproductive period ${ }^{26}$, making ingestion of the fish more dangerous just before and during reproduction ${ }^{2}$. TTX and STX act by blocking the extracellular-opening of the pore locus of voltage dependent sodium receptors, preventing depolarization and propagation of action potential in nerve cells. This action occurs in the peripheral motor, sensory and autonomic nerves ${ }^{10,16}$. TTX also acts by depressing the respiratory and vasomotor center of the encephalic trunk ${ }^{4}$. Death can occur due to muscle paralysis, respiratory depression, and circulatory failure ${ }^{10}$. There are reports of human death by bradycardia not responsive to any treatment (total atrioventricular blockage $)^{14}$.

STX is responsible for paralytic shellfish poisoning (PSP) ${ }^{10}$ which causes a range of symptoms similar to TTX envenomation ${ }^{16}$. Although not usually targeted, STXs have been incidentally found in numerous species of fish such as Colomesus asellus and some species of Sphoeroides. Like TTX, STX is found in the skin, muscle, gut contents, gonads and liver ${ }^{1,8,17,19}$.

Despite their toxicity, some species of puffer fish are considered a delicacy. In Japan, the Fugu (puffer fish of Fugu genus) is an expensive food prepared by specially trained chefs. When properly prepared, small amounts of toxin in the fish can produce perioral paresthesias ${ }^{9}$. Despite careful preparation, fatal envenoming by Fugu are common in Japan, with about 50 deaths recorded each year. This intake of puffer fish meat may be accidental or intentional (e.g. attempted suicide) ${ }^{14}$.

In Brazil, where there are few studies of this kind of poisoning and no epidemiological data, there are only scattered reports of deaths and serious poisonings $\mathrm{s}^{3,12}$.

The smooth puffer fish of the Tetrodontidae family is the most commonly consumed in Brazil, specifically Lagocephalus lagocephalus and Lagocephalus laevigatus, but species of the genus Sphoeroides are also consumed by fishermen, and their families (Sphoeroides spengleri and Sphoeroides testudineus, the latter most commonly). The Lagocephalus puffer fish has a yellow/green coloration (and is thus known as the "macaw or green puffer fish") and the Sphoeroides are gray with

(1) Centro de Informações Toxicológicas de Santa Catarina, Universidade Federal de Santa Catarina, Florianópolis, SC, Brasil (cit@hu.ufsc.br).

(2) Departamento de Patologia, Universidade Federal de Santa Catarina, Centro de Informações Toxicológicas de Santa Catarina, Florianópolis, SC, Brasil.

(3) Centro de Informações Antiveneno da Bahia, Hospital Roberto Santos, Salvador, BA, Brasil (ciave@ saude.ba.gov.br).

(4) Faculdade de Medicina de Botucatu, Universidade Estadual Paulista, Botucatu, SP, Brasil (haddadjr@fmb.unesp.br).

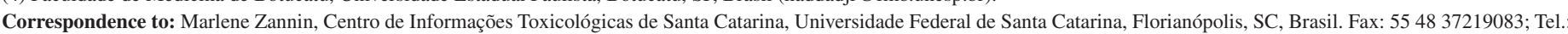

554837218085. E-mail: cit@hu.ufsc.br, zannin@ccs.ufsc.br 


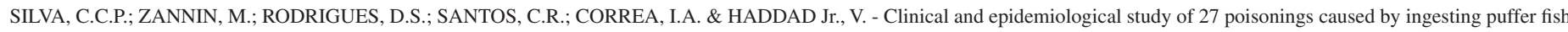
(Tetrodontidae) in the states of Santa Catarina and Bahia, Brazil. Rev. Inst. Med. Trop. Sao Paulo, 52(1): 51-55, 2010.

variable dark spots (and thus known as spotted puffer fish) (Fig. 1 and 2). A study in Brazil identified the components responsible for toxicity in Colomesus asellus, a freshwater species found in the Amazon region, to be saxitoxin and gonyautoxin ${ }^{4,10}$, toxins associated with PSP and not $\mathrm{TTX}^{23}$. Another study of Sphoeroides spengleri, a species found along the Atlantic coast, detected TTX and analogues (anhydro-TTX, Tetrodonic Acid and 4-epi-TTX): OLIVEIRA et al. (2003) $)^{22}$ showed that TTX levels in muscle, skin, and viscera from fish of the Sphoeroides genus are high and a risk to consumers, whereas levels in Lagocephalus genus are low and in theory present a lower degree of risk. Extracts from $S$. spengleri showed high toxicity, and, skin and viscera were the most toxic tissues. Toxin concentrations varied from $46.5 \pm 4.05$ up to $352.5 \pm 49.23$ in muscle and $78.2 \pm 7.61$ up to $946.4 \pm 60.83$ in skin plus viscera ${ }^{22}$.

Symptoms usually begin within six hours, but some patients may take up to 20 hours to present manifestations ${ }^{14}$. Perioral paresthesias, weakness of facial muscles and extremities, abdominal pain, drooling, nausea, vomiting, and diarrhea occur early. Patients may have motor dysfunction with muscular weakness, hypoventilation, and dysarthria. Ascending paralysis occurs in 4-24h, with paralysis of the extremities followed by paralysis in respiratory muscles. Late cardiac dysfunction can be observed and central nervous system manifestations with hypotension and arrhythmias, as well as coma and convulsions. Bradycardia refractory to treatment and atrio-ventricular node blockage can be fatal. Patients

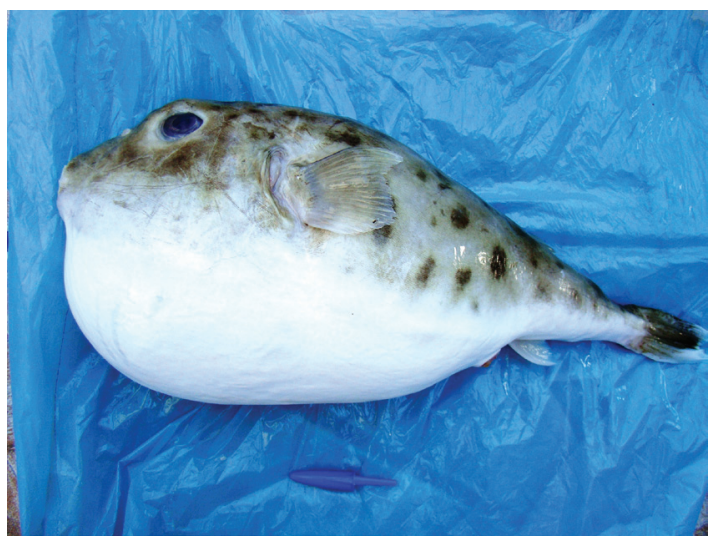

Fig. 1 - Sphoeroides testudineus, one species of checkered puffer fish associated with human poisonings in Brazil. Photo by: Vidal Haddad Jr.

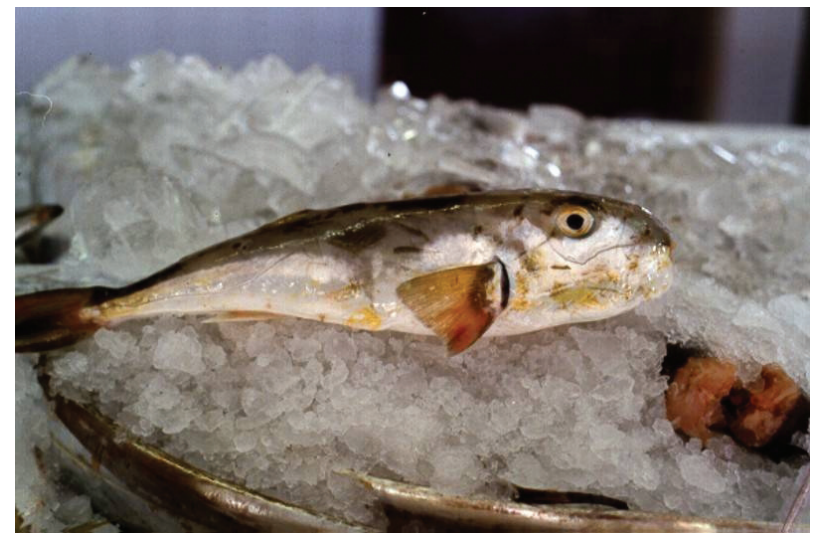

Fig. 2 - In the Brazilian coast the Lagocephalus genus has lower levels of tetrodotoxin than Sphoeroides and is not considered a dangerous food by fishermen. Photo by: Vidal Haddad Jr. with severe poisoning may enter a deep coma, have fixed and non-reactive pupils, apnea, and absence of encephalic trunk reflexes ${ }^{4}$. Victims who survive the acute phase of intoxication (the first 24 hours), usually recover without long term consequences ${ }^{4,10,14}$, but full recuperation may take days. Diagnosis is based on clinical history and a report of the consumption of puffer fish ${ }^{26}$. Quantitative analysis of TTX by High Performance Liquid Chromatography (HPLC) of unconsumed portions of the fish and/or victim urine and serum confirms the diagnosis ${ }^{15}$. Urine exam in the first 24 hours after consumption seems to be the most sensitive method for detecting poisoning by $\mathrm{TTX}^{21}$.

There is no antidote, and the treatment is focused on responding to manifested signs and symptoms. Detoxification measures such as gastric lavage and the use of activated charcoal may be useful in the early stages. In severe cases, mechanical ventilation and inotropic medication are useful ${ }^{10}$. Continuous ECG monitoring and pulse oximetry over 1-2 days are indicated in patients with moderate symptoms when an intensive care unit is not available. Respiratory monitoring is vital in the intensive care unit for the first 24 hours in patients with marked respiratory failure ${ }^{14}$. A study in mice using monoclonal antibodies for TTX showed a protective effect against poisoning with lethal doses of the toxin, but until now no attempt has been performed on humans and supportive care is the only effective treatment employed ${ }^{25}$.

\section{MATERIALS AND METHODS}

This study evaluates the incidence, clinical manifestations and circumstances of poisonings and their development, including complications from poisonings caused by patients ingesting puffer fish who were seen at two specialized toxicological centers in Brazil: 1) CIT/SC - Center for Toxicological Information, in Santa Catarina State, from 1984 to January 2009; 2) CIAVE - Center for Information on Antivenoms, in Bahia State, from 1984 to 1990. It also compares the incidence of poisoning by puffer fish with the incidence of accidents with other venomous and poisonous animals treated at CIT / SC during the studied period. Data were extracted from attendance records, but all cases were observed and treated by members of both Centers. Santa Catarina State is located in Southern Brazil, is a popular tourist destination, and has a large number of fishing communities, as does the Bahia State, located in the Northeast of Brazil. Both states border the Atlantic Ocean.

Cases in Santa Catarina were analyzed for: locality and area of occurrence; gender, age, and occupation of the patient; year of occurrence; quantity of meat ingested; hospitalization; circumstances of the poisoning; clinical manifestations; time elapsed between ingestion and symptoms onset; need of hospitalization; and clinical follow-up. Age was not reported in one questionnaire, victim occupation and the location of accident occurrence was not reported in three questionnaires, and puffer fish meat intake was only reported for six patients. In two cases there was no follow-up, making it impossible to determine their evolution. In Bahia, data were collected for gender, patient clinical evolution and clinical manifestation.

Puffer fish poisoning diagnosis was based on a typical history of recent consumption of puffer fish meat and the development of gastrointestinal and neurological symptoms consistent with intoxication for TTX/STX. Clinical classification of poisoning severity was based 


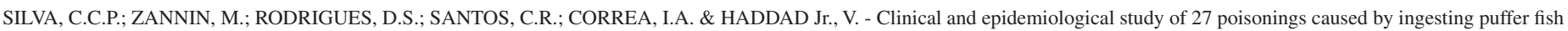
(Tetrodontidae) in the states of Santa Catarina and Bahia, Brazil. Rev. Inst. Med. Trop. Sao Paulo, 52(1): 51-55, 2010.

Table 1

Circumstances of poisonings caused by puffer fish observed at CIT/SC

\begin{tabular}{|c|c|c|c|c|c|c|c|c|c|c|c|c|c|}
\hline \multicolumn{2}{|c|}{ Year of occurrence } & \multicolumn{2}{|c|}{ Gender } & \multicolumn{2}{|c|}{ Age(years) } & \multicolumn{2}{|c|}{ Occupation } & \multicolumn{2}{|c|}{ Place of occurrence } & \multicolumn{2}{|c|}{ Circumstances } & \multicolumn{2}{|c|}{ Amount } \\
\hline 1985 & 3 & female & $9(41 \%)$ & $0-10$ & $3(14 \%)$ & fishermen & $2(9 \%)$ & & & & & & \\
\hline 1999 & 3 & male & $13(51 \%)$ & $10-20$ & $3(14 \%)$ & $\begin{array}{l}\text { home } \\
\text { worker }\end{array}$ & $1(4.5 \%)$ & outdoors & $4(18 \%)$ & $\begin{array}{l}\text { food } \\
\text { intake }\end{array}$ & $21(95.5 \%)$ & 3 fillets & $2(9 \%)$ \\
\hline 2000 & 2 & & & $21-30$ & $2(10 \%)$ & $\begin{array}{l}\text { security } \\
\text { guard }\end{array}$ & $1(4.5 \%)$ & home & $14(64 \%)$ & $\begin{array}{l}\text { attempted } \\
\text { suicide }\end{array}$ & $1(4.5 \%)$ & liver & $3(14 \%)$ \\
\hline 2001 & 5 & & & $31-40$ & $2(10 \%)$ & unknown & $18(82 \%)$ & unknown & $4(18 \%)$ & & & unknown & $17(77 \%)$ \\
\hline 2003 & 5 & & & $41-50$ & $8(38 \%)$ & & & & & & & & \\
\hline 2005 & 1 & & & over 50 & $3(10 \%)$ & & & & & & & & \\
\hline 2009 & 3 & & & & & & & & & & & & \\
\hline
\end{tabular}

on neurological assessments using CIT/SC criteria $^{9}$ which are similar to classifications found in the literature ${ }^{11}$ :

- Mild: gastrointestinal symptoms;

- Moderate: mild neurological and gastrointestinal symptoms;

- Serious: gastrointestinal and neurological symptoms with respiratory depression and convulsions.

\section{RESULTS}

22 cases were studied in Santa Catarina State and five in Bahia State, of them 18 male (67\%) and nine female (33\%) patients. All the cases were related to fish from marine habitats. Most cases (52\%) were classified by the authors as moderately severe poisonings, and there were nine severe cases. Poisoning severity was also classified according to FUKUDA \& TANI, $1941^{11}$. Two patients died and 23 left the hospital completely recovered.

As can be seen in Table 1, in Santa Catarina State, cases involving males were predominant (59\%). The highest incidence was in patients in their forties (38\%) and three cases (14\%) occurred in children. Most cases occurred at the patient's home, and in one case of puffer fish ingestion was an attempted suicide (Table 1).

The clinical manifestations in the patients from Santa Catarina State included neurological impairment in $46 \%$ of cases, gastrointestinal and neurological symptoms in 45\%, and gastrointestinal symptoms alone in $9 \%$. Recovery was observed in $86 \%$ and one patient died. Neurological manifestations were observed in $91 \%$ of patients; $57 \%$ of these also presented gastrointestinal symptoms. The main signs/symptoms presented by patients were: paresthesias, vomiting, nausea, dizziness, abdominal pain, dyspnea, respiratory failure, and muscle paralysis. Other less common symptoms were malaise, weakness, hypotension, muscle fasciculation, ataxia, aphonia, and coma (Table 2). In 2000, one patient who had eaten puffer fish liver developed oral and extremity paresthesias, tetraparesis, ataxia, and vomiting. The patient underwent electromyography in the initial phase of admission, which showed median and ulnar nerve alterations.

All the patients in Bahia State were male. Of these, $40 \%$ were classified as suffering mild, $20 \%$ as moderate, and $40 \%$ as severe poisoning. Four patients cured and there was one death. Most patients
$(60 \%)$ displayed concomitant gastrointestinal and neurological symptoms; no patient had only neurological symptoms. The main signs/symptoms were vomiting, paresthesia, nausea, abdominal pain, and respiratory failure (Table 2 ).

Table 2

Patient clinical manifestations

\begin{tabular}{lccc}
\hline Clinical manifestations & SC & Bahia & Total \\
\hline Vomiting & 10 & 3 & $13(48 \%)$ \\
Paresthesias & 10 & 2 & $12(44 \%)$ \\
Nausea & 9 & 2 & $11(41 \%)$ \\
Dizziness & 6 & 0 & $6(22 \%)$ \\
Abdominal pain & 4 & 2 & $6(22 \%)$ \\
Dyspnea & 5 & 1 & $6(22 \%)$ \\
Respiratory failure & 4 & 2 & $6(22 \%)$ \\
Muscular paralysis & 6 & 0 & $6(22 \%)$ \\
Muscular weakness & 4 & 0 & $4(15 \%)$ \\
Fasciculation & 4 & 0 & $4(15 \%)$ \\
Ataxia & 4 & 0 & $4(15 \%)$ \\
Malaise & 2 & 1 & $3(11 \%)$ \\
Coma & 3 & 0 & $3(11 \%)$ \\
Cardiopulmonary arrest & 2 & 1 & $3(11 \%)$ \\
Arterial hypotension & 2 & 0 & $2(7 \%)$ \\
Aphonia & 1 & 0 & $1(4 \%)$ \\
Diarrhea & 0 & 0 & $0(0 \%)$ \\
Convulsions & 0 & 0 & $0(0 \%)$ \\
Body systems manifestations & & & \\
Neurological & 10 & 0 & $10(37 \%)$ \\
Gastrointestinal & 2 & 2 & $4(15 \%)$ \\
Neurologic and gastrointestinal & 10 & 3 & $13(48 \%)$ \\
\hline Evolution & & & \\
Cure & 19 & 4 & $23(86 \%)$ \\
Cure not confirmed & 0 & $2(7 \%)$ \\
Death & 1 & $2(7 \%)$ \\
\hline
\end{tabular}




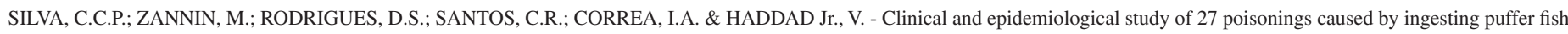
(Tetrodontidae) in the states of Santa Catarina and Bahia, Brazil. Rev. Inst. Med. Trop. Sao Paulo, 52(1): 51-55, 2010.

The survey of data from the Santa Catarina State Center for Toxicological Information found a total of 65,848 attendees with 13,898 cases of accidents caused by poisonous and venomous animals in the reported period. Poisonings caused by puffer fish ingestion represented $0.046 \%$ of the total and $0.21 \%$ of accidents caused by poisonous and venomous animals.

\section{DISCUSSION}

Unlike Japan where they are considered a delicacy and prepared by chefs who have been specially trained for years, and still not always safe for consumption ${ }^{10}$, puffer fish are not part of Brazilian cuisine. This study shows that poisonings caused by puffer fish ingestion occur mostly through accidents in the house of the victim - sometimes with entire families - and occasionally in fishermen from the fishing communities. The lack of information about the possibility of poisoning can result in higher severity or lethality. We observed more moderate and serious cases (52\% and $33 \%$ respectively) than mild cases (only 15\%), highlighting the potency of the puffer fish poison (TTX and STX analogues). Another factor that can influence severity and prognosis is the quantity of toxin ingested ${ }^{14}$. It was possible to determine the amount of ingested puffer fish in five cases: in two cases three fillets were ingested and in three cases the liver was ingested. In the case of fillets, it is known that muscle is not the preferred site for TTX accumulation ${ }^{12}$, but STX may be found in elevated concentrations in muscle ${ }^{1,8,24}$. On the other hand, risk is known to be greater from liver ingestion because this organ may have very high levels of TTX. In most cases, however, the amount of toxins ingested remained undetermined.

The low number of cases evidenced by this study, during the period analyzed, indicates that puffer fish poisoning is rare in Brazil, but usually involves more than one person, in situations where a family or group are known to have eaten the fish. The predominance of young male patients reflects the higher consumption of puffer fish by fishery workers. The occurrence of a case involving a suicide attempt demonstrates some local knowledge about the risks of ingesting these fish.

The use of two poisoning severity classification systems allows comparing their methods. The similarity in the quantity of higher severity cases shows a correlation between the methods for stratification in serious cases, with no doubts about potentially fatal cases. However, in patients with less severe manifestations, the classifications showed discrepancies. In the Fukuda and Tani classification ${ }^{11}$, twice as many patients were categorized as less severe than in the classification used by these authors. Establishing a diagnosis based on clinical findings and on the history of recent consumption is supported by the scientific literature and by the difficulty of performing laboratory testing ${ }^{5,6,26}$. Until now, only one sensitive technique for determining the TTX concentration in intoxicated patients has been reported in the literature, which is urine collection in the 24 hours following ingestion ${ }^{21}$. This test, however, is not yet available in Brazil.

The symptoms displayed by different patients reflect the broad range of effects secondary to the action of puffer fish toxins on the central and peripheral nervous system. The small percentage of patients with gastrointestinal symptoms alone (15\%) compared with $85 \%$ of patients with neurological symptoms shows the powerful effect of TTX/
STX on peripheral nerves, by its action on voltage dependent sodium channels. The considerable proportion of patients with symptoms related to respiratory dynamics highlights the need for adequate respiratory support to improve patient prognosis. Patients with respiratory failure are recommended to receive respiratory monitoring in intensive care units in the first 24 hours $^{14}$. Because there is no antidote ${ }^{26}$, early cardiovascular and respiratory support is very important to improve the patient's outcome.

Despite the low number of poisonings from puffer fish ingestion compared to the total number of cases seen at CIT/SC, the potential lethality indicates the importance of adequate patient support. The description of the circumstances and the clinical conditions of these poisonings contributes to knowledge about accidents from puffer fish ingestion in Brazil and clarifies the clinical effects of this neurotoxin.

In Pacific regions, puffer fish toxicity is usually related to the presence of TTX $^{24}$. In Florida's marine waters (USA), puffer fish have been confirmed to be a hazardous reservoir of $\mathrm{STX}^{17}$ and this toxin was responsible for 28 poisoning cases between 2002 and $2004^{8}$. A study in Brazil identified saxitoxin and gonyautoxin as the components responsible for toxicity in Colomesus asellus, a freshwater puffer fish ${ }^{23}$. Without further studies to identify the toxins related to puffer fish poisonings, it is not possible to assume which toxin caused the symptoms of puffer fish poisoning in the regions of this study.

Due to the diverse clinical presentation of TTX/STX poisoning, in patients with gastrointestinal and neurological symptoms and a history of recent fish consumption, it is important that the possibility of puffer fish poisoning not be ruled out and, in addition, to ask about puffer fish consumption from other people. Despite the evidence of increased possible poisoning from consuming meat of the Sphoeroides genus, the spotted puffer fish ${ }^{13,23}$, the general public and fishermen have little knowledge about the puffer fish species. Therefore, based on our study, we do not recommend consumption, even in small amounts, of flesh and other tissues of puffer fish. Educational measures in targeted populations (e.g. fishing communities) could be useful to prevent puffer fish poisoning.

Early diagnosis is very important in this type of poisoning. The need to apply respiratory support in moderate and severe cases and the absence of specific treatment reinforces the need of more studies to improve the prognosis in cases of ingestion.

\section{RESUMO}

\section{Estudo clinico-epidemiológico de 27 envenenamentos causados pela ingestão de baiacus (Tetrodontidae) nos estados de Santa Catarina e Bahia, Brasil}

Os baiacus ou peixes-bola podem ser venenosos devido à presença em seus tecidos corporais de Tetrodotoxina e/ou Saxitoxina, ambas potentes neurotoxinas. Os autores relatam 27 envenenamentos por ingestão da carne de baiacus. Os pacientes foram atendidos nos Centros de Toxicologia de Santa Catarina e da Bahia de 1984 a 2009. Os acidentes foram classificados em moderados (52\%) e graves (33\%), havendo dois óbitos. O diagnóstico precoce é fundamental no sentido de garantir suporte ventilatório aos pacientes. 


\section{REFERENCES}

1. Abbott JP, Flewelling LJ, Landsberg JH. Saxitoxin monitoring in three species of puffer fish. Harmful Algae. 2009;8:343-8.

2. Ahasan HA, Mamun AA, Karim SR, Bakar MA, Gazi EA, Bala CS. Paralytic complications of puffer fish (tetrodotoxin) poisoning. Singapore Med J. 2004;45:73-4

3. Almeida VG, Rocha CM. Registros de acidentes com peixes peçonhentos e/ou venenosos. Rev Soc Bras Toxicol. 1989;2:49-51.

4. Benzer TI. Toxicity, Tetrodotoxin [on line]. The eMedicine Clinical Knowledge Base [cited 2009 July 14]. Available from: http://emedicine.medscape.com/article/818763overview.

5. Center for Diseases Control and Prevention (US). Tetrodotoxin poisoning associated with eating Puffer fish transported from Japan - California, 1996. Morb Mortal Wkly Rep. 1996;45:389-91.

6. Chowdhury FR, Nazmul Ahasan HA, Mamunur Rashid AK, Al Mamun A, Khaliduzzaman SM. Tetrodotoxin poisoning: a clinical analysis, role of neostigmine and short-term outcome of 53 cases. Singapore Med J. 2007;48:830-3.

7. Deeds JR, Landsberg JH, Etheridge SM, Pitcher GC, Logan SW. Non-traditional vectors for paralytic shellfish poisoning. Mar Drugs. 2008;6:308-48.

8. Deeds JR, White KD, Etheridge SM, Landsberg JH. Concentrations of saxitoxin and tetrodotoxin in three species of puffers from the Indian River Lagoon, Florida, the location for multiple cases of saxitoxin puffer poisoning from 2002 to 2004. Trans. Am Fish Soc. 2008;137:1317-26.

9. Dos Santos CR, Neves FF, De Lima L, Grando M, Benato VS, França FOS, et al. Occurrence of poisoning by ingestion of baiacu. Rev Ciênc Saúde. 1996;15:253-63.

10. Field J. Puffer fish poisoning. J Accid Emerg Med. 1998;15:334-6.

11. Fukuda A, Tani A. Records of Puffer poisonings. Nippon Igaku Oyobi Kenko Hoken. 1941;3528:7-13.

12. Haddad Jr V. Animais aquáticos de importância médica no Brasil. Rev Soc Bras Med Trop. 2003;36:591-7.

13. Haddad Jr V, Takehara ET, Rodrigues DS, Lastoria JC. Envenenamentos por baiacus (peixes-bola): revisão sobre o tema. Diagnóstico \& Tratamento. 2004;9:183-5.

14. How CK, Chern CH, Huang YC, Wang LM, Lee CH. Tetrodotoxin poisoning. Am J Emerg Med. 2003;21:51-4
15. Isbister GK, Son J, Wang F, Maclean CJ, Lin CS, Ujma J, et al. Puffer fish poisoning: a potentially life-threatening condition. Med J Aust. 2002;177:650-3.

16. Isbister GK, Kieman MC. Neurotoxic marine poisoning. Lancet Neurol. 2005;4 219-28.

17. Landsberg JH, Hall S, Johannessen JN, White KD, Conrad SM, Abbott JP, et al. Saxitoxin puffer fish poisoning in the United States, with the first report of Pyrodinium bahamense as the putative toxin source. Environ Health Perspect. 2006;114:1502-7.

18. Lau FL, Wong CK, Yip SH. Puffer fish poisoning. J Accid Emerg Med. 1995;12:214-5.

19. Nakamura M, Oshima Y, Yasumoto T. Occurence of saxitoxin in puffer fish. Toxicon $1984 ; 22: 381-5$

20. National Geographic Society. Pufferfish - Tetraodontidae [on line, cited 2009 July 14]. Available from:http://animals.nationalgeographic.com/animals/fish/pufferfish html.

21. O'Leary MA, Schneider JJ, Isbister GK. Use of high performance liquid chromatography to measure tetrodotoxin in serum and urine of poisoned patients Toxicon. 2004;44:549-53.

22. Oliveira JS, Pires Jr OR, Morales RAV, Bloch Jr C, Schwartz CA, Freitas JC. Toxicity of Puffer fish: two species (Lagocephalus laevigatus, Linaeus 1766 and Sphoeroide spengleri, Bloch 1785) from the Southeastern Brazilian coast. J Venom Anim Toxins Incl Trop Dis. 2003;9:76-88.

23. Oliveira JS, Fernandes SC, Schwartz CA, Bloch Jr C, Melo JA, Pires Jr OR, et al. Toxicity and toxin identification in Colomesus asellus, an Amazonian (Brazil) freshwater puffer fish. Toxicon. 2006;48:55-63.

24. Quilliam M, Wechsler D, Marcus S, Ruck B, Wekell M, Hawryluk T. Detection and identification of paralytic shellfish poisoning toxins in Florida pufferfish responsible for incidents of neurologic illness. In: Steidinger KA, Landsberg JH, Tomas CR, Vargo GA, editors. Harmful Algae 2002 St. Petersburg: Florida Fish and Wildlife Conservation Commission, Florida Institute of Oceanography, and Inter-governmental Oceanographic Commission of United Nations Educational, Scientific and Cultural Organization; 2004. p.116-118.

25. Rivera VR, Poli MA, Bignami GS. Prophylaxis and treatment with a monoclonal antibody of Tetrodotoxin poisoning in mice. Toxicon. 1995;33:1231-7.

26. Sobel J, Painter J. Illnesses caused by marine toxins. Clin Infec Dis. 2005;41:1290-6.

Received: 25 September 2009

Accepted: 18 December 2009 